\title{
The Attractivity of Ornamental Plants to Some Natural Enemies of Pest
}

\author{
Fatima Ramdan Muhamed Al Kawan ${ }^{1}$, Bagyo Yanuwiadi², Zaenal Fanani ${ }^{3}$ \\ ${ }^{1}$ Department of Environmental and Development, Graduate Program, Brawijaya University, Malang, Indonesia \\ ${ }^{2}$ Department of Biology, Faculty of Mathematics and Natural Sciences, Brawijaya University, Malang, Indonesia \\ ${ }^{3}$ Faculty of Animal Husbandry, Brawijaya University, Malang, Indonesia
}

\begin{abstract}
There are several roles of ornamental plants to environment management and human being. One of them is to attract some natural enemies of pest which more ecofriendly and specific target. Related with this role, the objectives of this study are to inventory kind of ornamental plants in the play ground, to inventory kind of ornamental plants which attract natural enemies, and to know the foreign students perception to the function of the ornamental plant species for attracting the natural enemies. This study was conducted using Visual Encounter Survey (VES) method with three repetitions. The result showed that there were 5 ornamental plants in the area study as Acalypha siamensis, Osmoxylon lineare, Canna indica, Crinum asiaticum L. and Oleina syzigium. Data analysis using Community structure of Arthropods, Index of Diversity, and Index of Similarity on different area. The result Based on the average of species abundance, $O$. lineare is the most visited plant by animals. It was showed from range of average of species abundance which reached from 0.17 to 13.72 individu. The second one was $A$. siamensis which had average of species abundance $0.14-13.14$ individu. The next plant which visited by many animals are $C$. indica and $C$. asiaticum L. The average of species abundance respectively varied from 0.43 to 12.00 individu and from 0.14 to 8.72 individu. Oleina syzigium became the least one, because the average of species abundance reached from 0.14 to 3.14 individu. Overall, the level of respondents (foreign students) knowledge about the function of ornamental plants for attracting natural enemies was categorized into high
\end{abstract}

Key words: Attractivity, Natural enemies, Ornamental plants

\section{INTRODUCTION}

Ornamental plant is plant with higher value of cultural and amenity rather than nutritional value in life, so it can be considered as important sector for horticulture industry (Debroes, 2011). The word ornamental composed a wide array of plant and classified into several groups such as cute flowers, ornamental grasses, lawn or turf grasses, potted and indoor plants, bedding plants, trees and shrubs. Ornamentals plants has many usage, usually use in floristry, to increase aesthetics values of garden, to landscape, and to increase environmental value and comfort (Debroes, 2011; Chandler \& Sanchez, 2012).

With the high of amenity and cultural value, ornamental plant usually can be find in garden and parks. Flower visiting insects so attracted with ornamental plant that grown in urban area (Comba et al., 1999; Pawelek et al., 2009). Natural enemies are organisms that can kills other animals, either is pest or not. Example of natural enemies for a pest is predators and parasites. Natural enemies can be used to protect crops from the pest because it has very important role to control populations, without natural enemies pest populations will explode (IPM, 2017)

Biological control can't be separated from natural enemies and most of the natural enemies are insects. Kinds of insect that can be used for biological control were predators, parasites, and pathogens. Important plant resources for phytophagous insects such as a weeds, flowers, and other species of plants. Beneficial insects can be affected under influence of ornamental plant and weeds.

Natural enemies attracted by ornamental plant, and human can manipulate habitat to improve the suitability of natural enemies of pests. Conservation of natural enemies in agroecosystem to protecting the crops can be affected by some factor like antropohenic, soil and weather conditions, landscape diversity, and the presence of food souce, in this contex were nectar and pollen (Rodriguez-Saona et al., 2012).

Flowering plant was part of ornamental plat, so it can be assumed it can attracted natural enemies. The use of plants to attract beneficial insects and enhance their effectiveness is a form of conservation biological control referred to as habitat management (Landis et. Al. 2000). Given the current changes in agriculture, we were interested in exploring habitat management as a potential means of reducing reliance on pesticides.

\section{Purpose of the Research}

These are the objectives of the research: 
1. To inventory of ornamental plant species in the playground

2. To inventory of ornamental plant species that attract natural enemies.

3. To know the foreign students perception to the function of the ornamental plant species for attracting the natural enemies

\section{Benefits of the Research}

The result of this research will have benefit of academic and practical. The fist one is let student or people knows about species of ornamental plants and the arthropods that attracted by it, and also explain the function.

\section{METHOD}

\section{Time and Place}

This research was done on December2016 January 2017 at Malabar City Forest coordinate (7056'15,4" LS, 112 o32'03.2" BT). The Arthropods' sampling was taken in two different garden, that is garden 1 or gardens down with the altitude of 980 meters above sea level, The location of garden 1 is adjacent to the residential communities and the farms, as well as gardens 2 or garden on with the altitude of 996 meters above sea level, the location of garden 2 is adjacent to the forest.

\section{Data Collection \\ Sampling of Arthropods}

Sampling of arthropods was made in two different locations in Malabar City Forest. First plot was gardens down with the altitude of 980 meters above sea level and the second plot was gardens on with the altitude of 996 meters above sea level, the location of garden 2 is adjacent to the forest. The different of sampling locations were different based on geographical location. In this study, sample of Arthropods were obtained using Visual Encounter Survey (VES). Visual Encounter Survey method was one of sampling data by directly observing into the plants with a distance of 2 meters of the plant and carried out in specific moment. Every sampling had done with two different treatments, they were before and after spraying the pesticide. Sampling was done by five times of repetition. Every sampling was done four times during 15 minutes in orangery and block refugia in each garden, so there were 4 periods of observation in everyday for each garden. In the garden down of period 1 was started at 08:00-08:30 WIB, period 2 at 10:00-10:30, period 3 at 12:00-12:30 WIB and period 4 at 14:00-14:30 WIB, whereas period of the garden on was started at 09:00-09:30 WIB, period 2 at 11:00-11:30 WIB, period 3 at 13:0013:30 WIB, period 4 at 15:00-15:30 WIB. The next is to identify the level of family, and then number of the arthropods was noted and calculated.

\section{Data Analysis}

Arthropods type of data and amount of individual arthropods which has been obtained, then identified by using insect identification books. Identification was carried out until the family level. And then the data obtained processed by using Microsoft Office Excel with some calculation, such as:

\section{Community structure of Arthropod}

Analysis species abundance $(A)$ used to know number of individual species in one area. The formulation used to know the abundance as follows

\section{$A=\frac{\text { Total frequency of species }}{\text { Number of individuals oberved }}$}

Relative abundance (RA), analysis of relative abundance used to know the comparison number of individual species with total individual of all species. The formulation used to know the relative abundancel as follows:

\section{$R A=\frac{\text { Total number individual of species } i}{\text { इn Total number of individual of all species }} \times 100 \%$}

Frequency analysis (F) is used to know the opportunity in finding a species in sample plot. The formulation used to know the frequency as follows:

$A=\frac{\text { Total sampling species }}{\text { Total sample plots }}$

Analysis of relative frequency (RF) is aimed to compare between frequency of a species with the total of all the species. The formula used in finding out the relative frequency as follows:

$$
R F=\frac{\text { Frequency of one species }}{\text { Total frequency of all species }} \times 100 \%
$$

Analysis of Important Value index (IV) is aimed to know the influence of arthropods roles in its ecosystem. The formula used in finding out the IV as follows:

$$
I V=R A+R F
$$

$$
\begin{array}{ll}
\text { Note: } & \\
\text { IV } & =\text { Important Value Index (\%) } \\
\text { RA } & =\text { Relative Abundance (\%) } \\
\text { RF } & =\text { Relative Frequency (\%) }
\end{array}
$$




\section{Index of Diversity}

The analysis of index diversity can use ShannonWiener's diversity index $\left(\mathrm{H}^{\prime}\right)$ with the following formula;

$H^{s}=\sum_{i=1}^{s} p_{i} \ln p_{i}$

Note:

$\mathrm{H}^{\prime} \quad$ = Diversity index

$\mathrm{S}=$ Number of the species

pi $=$ Number of the species-i or number of individual in each species

Table 1. Score category of Shannon-Wiener diversity index

\begin{tabular}{cc}
\hline Score $\left(\mathbf{H}^{\prime}\right)$ & Environment Stability \\
\hline$<1$ & Very low \\
$>1-1$ & Low \\
$>\mathbf{2}-3$ & Medium \\
$>3-4$ & High \\
$>4$ & Very high \\
\hline
\end{tabular}

\section{Similarity of different sampling area}

Index of Bray Curtis can be used to determine the similarities of two areas were analyzed. Score 1 show the high level of similarity.

$$
I B C=1-\frac{\left(\sum|x i-y i|\right)}{\left(\sum x i+y i\right)}
$$

Note:

$\mathrm{IBC}=$ Similarity index of Bray-Curtis

$\mathrm{Xi}=$ Number of individual- $\mathrm{i}$ in the example $\mathrm{x}$

$\mathrm{Yi}=$ Number of individual-i in the example $y$

\section{RESULT AND DISCUSSION}

Variety ornamental plants observed in the playground

Most of ornamental plants are attractive plants which use for decorative purposes, include any plant cultured to serve a particular function (shade, windbreak and beautifying places. In this study was found five kind of ornamental plants such as Acalypha siamensis, Canna indica, Oleina syzigium, Crinum asiaticum L. and Miagos bush (Osmoxylon lineare).

\section{Acaplypha siamensis}

Acaplypha siamensis is one of shrub or small scrambling tree which growing up to $4 \mathrm{~m}$. As ornamental plants, usually $A$. siamensis also use as a raw material in the herbal and pharmaceutical industry which worth exploring. In traditional medicine, their leaves are used to treat fever, bowel complaints and kidney diseases because it may have antipyretic properties. Not only beneficial to the environment and the medical field but also in the food field, the leaves of this plant also can be used as tea-making materials. It is cultivated as a hedge in Thailand, Peninsular Malaysia and Indonesia (Fern, 2014).

\section{Canna indica}

Canna indica not only utilized as ornamental plants, but also utilized as food materials and support in medical field. Their rhizome are contains much carbohydrate which can use as body energy. Usually, $C$. indica has attractive flower with beautiful color. Canna genus are largely free of pest, but the plants sometimes fall victim to canna leaf rollers, or Brazillian skippers (Calpodes ethlius). It is the larva that is known for chewing straight rows of holes on canna leaves. Most types of feed as solitary caterpillars, but some feed in groups under a netting of their own silk. Beside caterpillars, slugs and snails sometime present in cannas. They can leave large holes in the leaves and prefer the tender young leaves that have not yet unfurled (Kessler, 2007).

\section{Oleina syzygium}

Oleina syzygium is a kind of shrub which have unique leaves. The color of the leaves is light green, with orange and red color at the tip of the young leaves. Newly emerging young plant heads will poke beautifully on the sidelines of the verdant leaves. Like a flower among the leaves. Apparently, this plant is still included in the same family with clove plants, Myrtaceae. When noted, the shape of the canopy and leaves are very much like a clove plant. In addition to the beauty, this plant can also be used to rehabilitate the land, prevent landslides and save water because it has a riding root that is able to enter into the soil ground strongly (Yadi, 2015).

\section{Crinum asiaticum}

Crinum asiaticum is plant which classified into Family Amaryllidaceae. Not only utilized as ornamental plant, but also widely used in indigenous medicine for many diseases. Type of this plant are bulb/tuber, perennial, and herbaceous. It has white flower which belong to year round flowering. It also produce pleasant fragrance. Crinum asiaticum may resistance toward the pest. In long term health usually it is not affected by pests. This plant is a very sturdy plant and is only occasionally bothered by 
caterpillars or other chewing insects (Yakandawala et al., 2006).

Miagos bush (Osmoxylon lineare)

Osmoxylon lineare is one of shrub that can grow up to $3 \mathrm{~m}$ tall. This plant was classified into Family Araliaceae. The other common names of this plant is Green Aralia (National Parks Board of Singapore, 2013).

Variety ornamental plants which visited by natural enemies of pest

In this study, the observation of plant-visitor animals was carried out on five different ornamental plant species including $A$. siamensis, $C$. indica, $O$. syzigium, $O$. lineare, and $C$. asiaticum $\mathrm{L}$. The results showed that the number of plantvisitor animals varied among the plants. Most of the animals observed belong to the group of Insects and Gastropods.

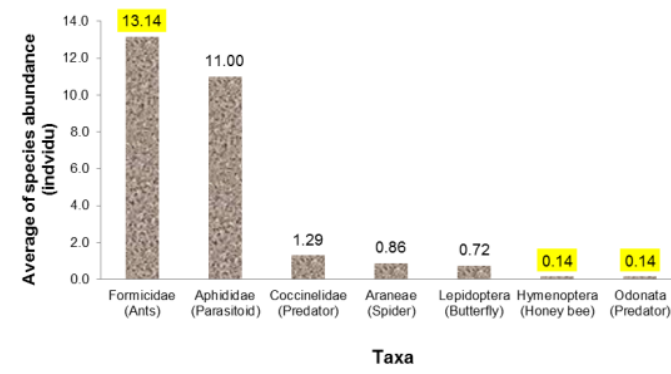

Figure 1. The abundance of species which observed arround Acalypha siamensis

The observation on $A$. siamensis showed that there were several observed insects belonging to the families Formicidae, Aphididae, Coccinelidae, Araneae, Lepidoptera, Hymenoptera and order Odonata. Formicidae and Aphididae were commonly observed taxa with average abundance value of 13.4, 11 individu, respectively. While, Hymenoptera and Odonata were taxa with the lowest observed abundance, 0.14 individu (Fig. 1). Based on spesies role in the ecosystem (niche), some taxa were classified into predator (Coccinelidae, Odonata, Araneae) and parasitoid (Aphididae).

There were nine different taxa that visited on $C$. indica namely Vespidae, Lepidoptera, Formicidae, Syrphidae, Coccinelidae, Braconidae, Araneae, Odonata and Pyralidae. The abundance of species found around $C$. indica plants ranged from 0.17 to 13.72 individu. Dominant taxa found was Vespidae, 12 individu, and the lowest was Pyralidae, 0.43 individu (Fig. 2).

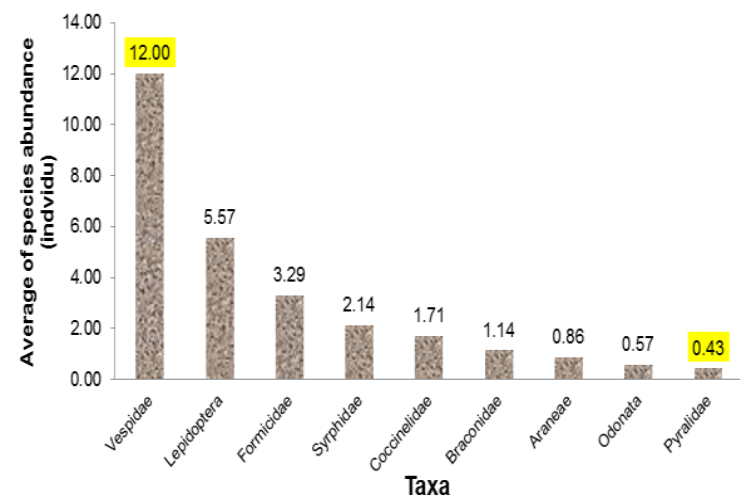

Figure 2. The average of species abundance which observed arround $C$. Indica

These insects found included the predatorparasitoid types. Predator was the most visited group of $C$. indica, it might be caused by the attractive characteristic of this plant such as flower or attractant substance. The attractant plants produced a distinctive aroma that able to attract predators. According to Asikaenen (2005), attractant plants generally had flowers with bright colors and produce a distinctive aroma that invited the insect predators. This was in accordance with the morphological of $C$. indica plants.

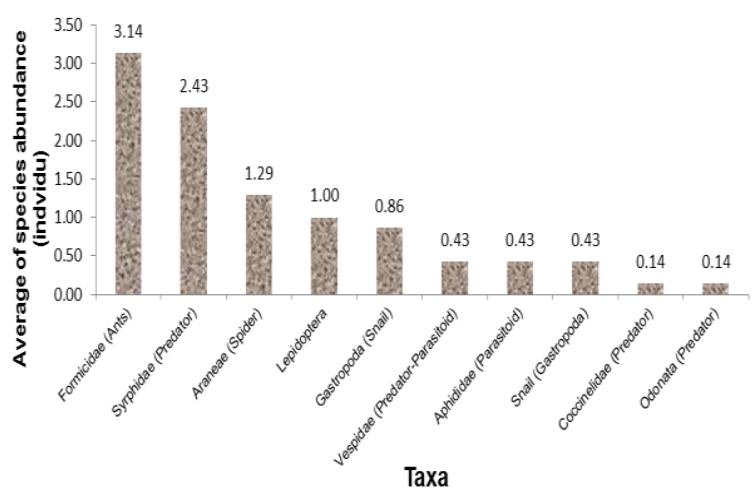

Figure 3. The average of species abundance which observed in $\boldsymbol{O}$. Syzigium

Different information was obtained form the observation of plant-visitor animals on $O$. syzygium. The observed species on this plant species was not only belong to Insect groups but also Gastropod or mollusc. Eight taxa were classified into some Insect groups including Formicidae, Syrphidae, Araneae, Lepidoptera, Vespidae, Aphididae, Coccinelidae, Odonata and one taxa was identified into Class Gastropod. In general, the species abundance of taxa found was not more than species abundance observed on $A$. siamensis and $C$. indica but high taxa 
richness was found here, ten taxa. Formicidae still became dominant species, 3.14 individu, and vice versa Coccinelidae and Odonata was the lowest, each of 0.14 individu, that observed on this plant species (Fig. 3). According to Andersen (2000), the low Formicidae abundance found on a plant species could be caused by limiting food resources, environment limiting factor, and less availabe home range.

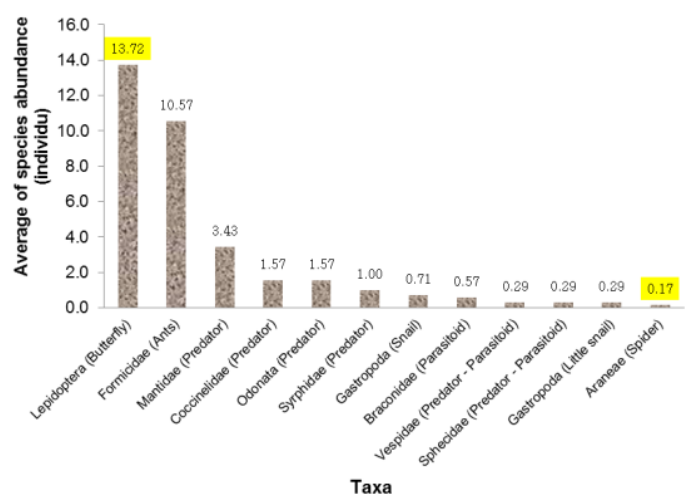

Figure 4. The average of species abundance which observed arround $O$. Lineare

The number of taxa found around Osmoxylon lineare (Miagos bush) were 11 groups including Lepidoptera, Formicidae, Mantidae, Coccinelidae, Odonata, Syrphidae, Gastropoda, Braconidae, Vespidae, Sphecidae and Araneae. The species abundance of these taxa ranged from 0.17 to 13.72 individu. The highest species abundance was owned by Lepidoptera while the lowest was Araneae group. The high abundance of Lepidoptera (13.72 individu) was thought to be due to this plant species provided resources (food, shelter) for Lepidoptera need (Fig. 4).

Crinum asiaticum had attractive flower with bright color. Based on that characteristic, it could automatically attract various kinds of insect. The highest taxa richness was observed on this plant species, 21 different taxa. This was greater than other four plant species discussed before. The average species abundance ranged from 0.14 to 8.72 individu with Odonata as dominant species found there. While, Coccinelidae, Mantidae, White Fleas, Mymaridae, Dermaptera, Iygaeidae Geocoris and Coniopterygidae were the lowest, 0.14 individu (Fig. 5).

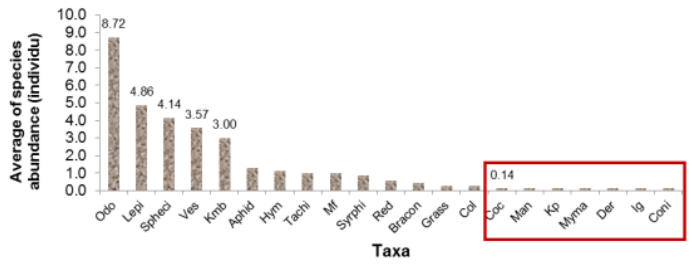

Figure 5. The average of species abundance which observed in C. asiaticum L. Note : Odo (Odonata); Lepi (Lepidoptera); Spheci (Sphecidae); Ves (Vespidae); Kmb (Kumbang madu besar); Aphid (Aphididae); Hym (Hymenoptera); Tachi (Tachinidae); Mf (Maelanoplos femurrubum); Syrphi (Syrphidae); Red (Reduvid); Bracon (Braconidae); Grass (Grassopper); Col (Coleoptera); Coc (Coccinelidae); Man (Mantidae); Kp (Kutu putih); Myma (Mymaridae); Der (Dermaptera); Ig (Iygaeidae Geocoris); Coni (Coniopterygidae).

Species could be found at 8.00-8.15 am and the smallest number was observed at 7.00-7.15 am (Fig. 4.11b). The result also informed that $O$. syzygium had number of observed species range of $15-50$ species. A total of 15 species was obtained at 7.00-7.15; 28 species at 8:00- 8:15; 32 species at 9.00-9.15 and 13.00-13.15; 41 species at $11: 00$ to $11: 15$ and $12: 00$ to $12: 15$. The largest number was observed from 10:00 to 10:15 am (Fig. 6c).

The number of observed species on $C$. asiaticum also varied at each observation time. The average number of species obtained over 20 species. The range of numbers was 27-36 species with following details, from the smallest to largest number, 27 species obtained at 7.00-7.15 and $8.00-8.15 ; 30$ species at $11: 00$ to $11: 15 ; 34$ species at $9.00-9.15 ; 35$ species at $12: 00$ to $12: 15$ and 36 species at $10: 00$ to $10: 15$ and $13: 00$ to 13:15 (Fig. 6e).

The perception of respondents (foreign students) about the function of ornamental plant species for attracting natural enemies

Interview was conducted on 20 respondents to know their perception of ornamental plants and natural enemies. There were six questions, as indicators, given to all respondents including knowledge of ornamental plants, knowledge of natural enemies of pests, knowledge of Arthropods often found in ornamental plants, the role of ornamental plants as natural enemies of pests, various ornamental plants, and various Insect visitors of ornamental plants. 

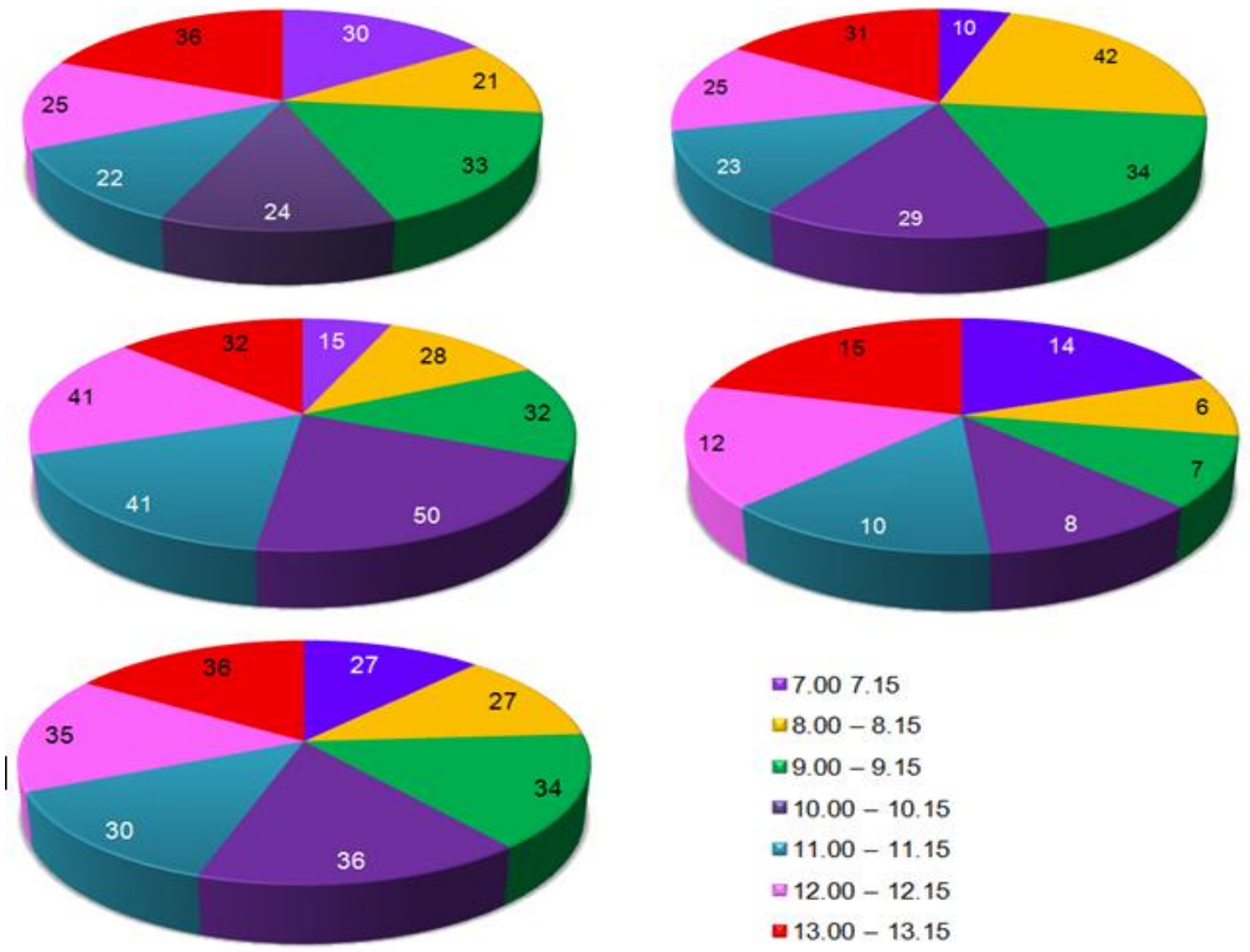

$$
\begin{aligned}
& \square 7.007 .15 \\
& \square 8.00-8.15 \\
& \square 9.00-9.15 \\
& \square 10.00-10.15 \\
& \square 11.00-11.15 \\
& \square 12.00-12.15 \\
& \square 13.00-13.15
\end{aligned}
$$

Figure 6. Variation number of species which observed in variation of time observation in a) A. siamensis; b) $C$. indica; c) $O$. syzygium; d) $O$. lineare and e) C. asiaticum



Figure 7. Perception of students about ornamental plants and its function, natural enemies based on Likert Scale

Based on calculations using the Likert Scale, all the indicator questions showed a value of more than 3.1. This informed that respondents had perception level between "neutral" and "know / high" against the indicator of the given question. Overall, all respondents could be categorized as having good knowledge about ornamental plants, natural enemies of pests, and the role of ornamental plants as natural enemies of pest, with Likert values 3.4, 3.7, 3.5, respectively. This Likert value indicated that the knowledge level of the respondents was high (Fig. 7).

Respondents had a level of knowledge that was categorized as "neutral" for questions about arthropods on ornamental plants, various ornamental plant species, and various insect visitor ofornamental plant visitor, with Likert values 3.2, 3.1, 3.1, respectively. The level of "neutral" perception or knowledge mean that the respondent had knowledge of arthropods, ornamental plants, ornamental visitors but the respondent could not give examples or name of the species (Fig. 7).

\section{CONCLUSION}

There were five ornamental plants which observed in conventional Mala Ban Florist City. It consisted of $A$. siamensis, $O$. lineare, $C$. indica, $C$. asiaticum $\mathrm{L}$. and $O$. syzigium. Based on variety of taxa, Crinum asiaticum $\mathrm{L}$. is the most visited plant by animals such as insects belonging to 21 groups. Miagos bush ( $O$. lineare) is the second plant which visited by many animals, not only 
insects but also snails. They were classified into 11 groups. The differences visited animals between both ornamental plants were $O$. syzigium also visited by Aphididae and Gastropod, while $C$. indica was visited by Braconidae and Pyralidae. Compared to four other ornamental plants, $A$. siamensis was the least visited animals. It just visited by insects that classified into seven groups. Based on the average of species abundance, $O$. lineare is the most visited plant by animals. It was showed from range of average of species abundance which reached from 0.17 to 13.72 individu. The second one was $A$. siamensis which had average of species abundance 0.14 - 13.14 individu. The next plant which visited by many animals are $C$. indica and $C$. asiaticum $L$. The average of species abundance respectively varied from 0.43 to 12.00 individu and from 0.14 to 8.72 individu. Oleina syzigium became the least one, because the average of species abundance reached from 0.14 to 3.14 individu.

The level of respondents (foreign students) knowledge about the function of ornamental plants for attracting natural enemies was categorized into high. This was based on Likert Scale calculation which showed high score, 3.5. This informed that respondents had good understanding about the role of the ornamental plant species for attracting natural enemies.

\section{REFERENCE}

[1]. Andersen A. N. 2000. Global ecology of Rainforest Ants: Functional Groups in Relation to Environmental Stress and Disturbance. In: Agosti D., Majer J. D., Alonso L. E., Schultz T. R. (eds). Ants: Standard Methods for Measuring and Monitoring Biodiversity. Volume 3. Smithsonian Inst, Amerika Serikat

[2]. Comba, L., Corbet, S.A., Barron, A., Bird, A., Collinge, S.,Miyazaki, N. and Powell, M. (1999a) Garden flowers: insect visits and the floral reward of horticulturally-modified variants.Annals of Botany, 83, 73-86

[3]. Chandler S and Sanchez C. (2012) Genetic modification; the development of transgenic ornamental plant varieties. Plant Biotechnology Journal 10, 891 - 903.

[4]. Dobroes, MS. 2011. Prospects for commercialization of transgenic ornamentals. In: Transgenic horticultural crops; challenges and opportunities (Moue B, and Sforza Reds.). Boca Raton, Florida: CRC press. pp 305 - 316.
[5]. Fern, Ken. 2014. Acalypha siamensis. Useful Tropical Plants. "http://tropical.theferns.info/viewtropical.p hp?id=Acalypha+siamensis". [05/05/2017]

[6]. Kessler, J. R. 2007. Canna lilies for Alabama Gardens. Alabama Cooperative Extension System ANR-1315. www.aces.edu. [06/05/2017].

[7]. Landis, D.A., S.D. Wratten and G.M. Gurr. 2000. Habitat management to conserve natural enemies of arthropod pests in agriculture. Annual Review of Entomology 45: 175-120.

[8]. Pawelek, J.C., Frankie, G.W., Thorp, R.W. and Przybylski, M.(2009) Modification of a community garden to attract native bee pollinators in urban San Luis Obispo, California.Cities and the Environment, 2, article 7

[9]. Purwaningsih, B. 2012. Kajian Komposisi Serangga Polinator Pada Tumbuhan Penutup Tanah di Poncokusumo malang. Jurnal Berk. Panel. Hayati: 165-172.

[10]. Rodriguez-Saone C., Versa N. Singh A. P., Johnson-Cicelies J., Szendrei Z. 2011. Tracing the history of plant traits under domestication in cranberries potential consequences on anti-herbivore defaces. J Expo Bot 62: 2633-2644.

[11]. JYadi. 2015. Penanaman Pohon pucuk merah (Oleina syzygium) untuk rehabilitasi lahan, mencegah longsor dan menyimpan cadangan air. "https://jatinangor.itb.ac.id/penanamanpohon-pucuk-merah-oleina-syzygium/. [05/05/2017].

[12]. Yakandawala D. M. D. and T. M. Samarakoon. 2006. An empirical study on the taxonomy of Crinum zeylanicum (L.) L. and Crinum latifolium L. (Amaryllidaceae) occurring in Sri Lanka. Cey. J. Sci. (Bio. Sci) 35 (1): 53-72. 